\title{
Strategies to Improve Immune Suppression Post-Liver Transplantation: A Review
}

\author{
Islam B Mohamed ${ }^{1,2} \mathbb{D}$, Fuad Z Aloor ${ }^{1}$ and Prasun K Jalal ${ }^{1, *(\mathbb{D})}$ \\ 1 Division of Gastroenterology, Baylor College of Medicine, Baylor Clinic 6620 Main Street, Suite 1450, \\ Houston, TX 77030, USA; islam.mohamed@bcm.edu (I.B.M.); fuadzain.aloor@bcm.edu (F.Z.A.) \\ 2 Department of Internal Medicine, Gastroenterology \& Hepatology, Ain Shams University, Cairo 11591, Egypt \\ * Correspondence: Jalal@bcm.edu; Tel.: +1-832-355-1424
}

Citation: Mohamed, I.B.; Aloor, F.Z.; Jalal, P.K. Strategies to Improve Immune Suppression Post-Liver Transplantation: A Review. Transplantology 2021, 2, 441-454. https://doi.org/10.3390/ transplantology2040042

Academic Editors: Vincenzo Ronca and Alessandro Parente

Received: 19 August 2021

Accepted: 14 October 2021

Published: 2 November 2021

Publisher's Note: MDPI stays neutral with regard to jurisdictional claims in published maps and institutional affiliations.

Copyright: (c) 2021 by the authors. Licensee MDPI, Basel, Switzerland. This article is an open access article distributed under the terms and conditions of the Creative Commons Attribution (CC BY) license (https:// creativecommons.org/licenses/by/ $4.0 /)$.

\begin{abstract}
Since the first liver transplantation operation (LT) in 1967 by Thomas Starzl, efforts to increase survival and prevent rejection have taken place. The development of calcineurin inhibitors (CNIs) in the 1980s led to a surge in survival post-transplantation, and since then, strategies to prevent graft loss and preserve long-term graft function have been prioritized. Allograft rejection is mediated by the host immune response to donor antigens. Prevention of rejection can be achieved through either immunosuppression or induction of tolerance. This leads to a clinical dilemma, as the choice of an immunosuppressive agent is not an easy task, with considerable patient and graft-related morbidities. On the other hand, the induction of graft tolerance remains a challenge. Despite the fact that the liver exhibits less rejection than any other transplanted organs, spontaneous graft tolerance is rare. Most immunosuppressive medications have been incriminated in renal, cardiovascular, and neurological complications, relapse of viral hepatitis, and recurrence of HCC and other cancers. Efforts to minimize immunosuppression are directed toward decreasing medication side effects, increasing cost effectiveness, and decreasing economic burden without increasing the risk of rejection. In this article, we will discuss recent advances in strategies for improving immunosuppression following liver transplantation.
\end{abstract}

Keywords: liver transplantation; immune tolerance; graft rejection; immunosuppressive drugs

\section{Introduction}

Liver transplantation (LT) is an expensive procedure, with the greatest cost in the first year and a considerable economic burden in the following years. A study from the USA for the estimation of the economic burden of LTs from 2008 to 2013 estimated that Medicare coverage reimbursed USD 185 thousand per recipient in the first year post-LT. The average cost after the first year was USD 154 thousand per recipient. The cost of re-transplantation was USD 388 thousand per-patient, and the costs in the second year post-LT were USD 28 thousand [1,2]. In a study by Serper and colleagues, nearly one-fifth of the recipients made tradeoffs for the medications post-LT that led to decreased compliance and increased hospital admissions. Insurance type, presence of co-morbid conditions, health literacy, and number of medications were associated with increased medication tradeoffs, decreased frequency of administration, or delayed purchase of the medications [3].

In addition to an increased economic burden, chronic use of immunosuppressive drugs leads to significant morbidities and metabolic side effects. While calcineurin inhibitors (CNIs) exhibit considerable nephrotoxicity and neurotoxicity, steroids are diabetogenic, and mycophenolic acid derivatives (MMFs) have adverse hematologic effects. Mammalian target of rapamycin inhibitors (MTORis) have been implicated in the development of interstitial lung disease. Different classes of immunosuppressive medications are associated with an increased infection rate. Immunosuppressive drugs used for rejection pose a high risk of demyelination and tuberculosis reactivation [4]. The long-term side effects of these drugs, including malignancies, opportunistic infections, metabolic disorders, and 
organ toxicities, represent the main clinical concern in formulating an immunosuppression protocol [5].

The 1-year survival post-LT improved to $85 \%$ after the introduction of CNIs in addition to the improvement of the recipients' selection and surgical techniques [6]. The overall survival is still multifactorial; medications' side effects, the rate of original disease recurrence, and the presence of comorbidities all play an important role when choosing the optimal immunosuppression protocol. Minimization of the side effects of the drugs without exposing patients to an increased risk of rejection is the ultimate goal for successful immunosuppressive protocols [7].

\section{Immunosuppression Protocols: The Past and the Present}

The evolution of immune suppression started in the 1950s, when irradiation was the only treatment option available. Then, the discovery of CNIs, azathioprine (AZA), steroids, and anti-thymocyte globulin (ATG) increased the one-year survival rate. CNIs claimed the highest potency of all immunosuppressive drugs, but nearly $20 \%$ of patients on CNIs experienced chronic renal failure at 5 years post-LT [8]. Early exposure to a high dose of CNIs is a driving force for renal damage [9].

Newer generations of immunosuppressive drugs are being tested in human and animal trials. Alemtuzumab is an anti-CD52 that depletes T cells, monocytes, and natural killer cells, and it can be used to reset the immune system. It showed promising results in chronic rejection. Belatacept interferes with T cell co-stimulation and can be used for the induction or maintenance of immunosuppression in LT. Efalizumab blocks T cells' responses to antigen-presenting cells (APCs), but it is not yet approved for LT. Eculizumab prevents the formation of complement complexes [10-12]. More recently, the use of cellular immunosuppression has addressed different interphases in immune response to grafts. Multiple trials have tested its ability to replace standard immunosuppression protocols [13] (Table 1: list of immunosuppressive medications, modes of action, and common side effects).

Table 1. List of immunosuppressive medications' modes of action, indications, and common side effects.

\begin{tabular}{|c|c|c|c|c|}
\hline $\begin{array}{c}\text { Year of Discovery/FDA } \\
\text { Approval }\end{array}$ & Indication & $\begin{array}{c}\text { Immunosuppressive } \\
\text { Agent }\end{array}$ & Mode of Action & Main Adverse Effect \\
\hline $\begin{array}{l}1972 / 1983 \\
\text { TAC in } 1994\end{array}$ & Maintenance & $\mathrm{CNI}$ & $\begin{array}{l}\text { Blocks protein transcription in } \\
\text { response to Il-2 and } \\
\text { prevents cellular proliferation }\end{array}$ & $\begin{array}{l}\text { Neurotoxicity } \\
\text { Nephrotoxicity } \\
\text { Diabetogenic }\end{array}$ \\
\hline 1893/1995 & Maintenance & MMF & Interferes with DNA synthesis & $\begin{array}{c}\text { Pancytopenia } \\
\text { Abdominal discomfort }\end{array}$ \\
\hline 1997 & AMR & Rituximab & Anti-CD 20 & Reactivation of TB \\
\hline 2007 & Maintenance & MTORi & $\begin{array}{l}\text { Inhibits cytokine receptor signal } \\
\text { transduction }\end{array}$ & $\begin{array}{l}\text { Hyperlipidemia } \\
\text { Pedal edema } \\
\text { Oral ulcers } \\
\text { HAT }\end{array}$ \\
\hline $1998 / 2008$ & Induction & Basiliximab & IL2 receptor blocker & Hypersensitivity \\
\hline \multirow[t]{2}{*}{2011} & $\begin{array}{l}\text { Induction or } \\
\text { maintenance }\end{array}$ & Balatacept & $\begin{array}{c}\text { Blocks CD80 co-stimulation } \\
\text { ligand }\end{array}$ & $\begin{array}{c}\text { Post-TX } \\
\text { lymphoproliferative } \\
\text { disorder }\end{array}$ \\
\hline & $\begin{array}{l}\text { Induction, } \\
\text { Maintenance, and } \\
\text { Rejection }\end{array}$ & Corticosteroids & $\begin{array}{l}\text { Affects the production of several } \\
\text { inflammatory mediators and } \\
\text { multiple cytokines, including } \\
\text { IL-1, IL-2, IL-3, IL-6, TNF-a, } \\
\text { IFN-Y, leukotrienes, and } \\
\text { prostaglandins }\end{array}$ & $\begin{array}{c}\text { Diabetes } \\
\text { Hypertension } \\
\text { Osteoporosis } \\
\text { Hirsutism } \\
\text { Weight gain }\end{array}$ \\
\hline 2014 & Chronic rejection & $\begin{array}{l}\text { Alemtuzumab } \\
\text { (Campath } 1 \mathrm{H})\end{array}$ & $\begin{array}{l}\text { Anti-CD52 on nucleated cells } \\
\text { of BM }\end{array}$ & $\begin{array}{c}\text { Hirsutism } \\
\text { Post-TX } \\
\text { Lymphoproliferative } \\
\text { disorder } \\
\end{array}$ \\
\hline 2017 & $\begin{array}{l}\text { Induction or } \\
\text { rejection }\end{array}$ & ATG & Anti-CD3 on lymphocytes & $\begin{array}{l}\text { Anaphylaxis, post-TX } \\
\text { lymphoproliferative } \\
\text { disorders }\end{array}$ \\
\hline
\end{tabular}


An approach to an immunosuppressive protocol can be patient-centered, where the immunosuppressive drugs are to be chosen according to pre-LT conditions and intraoperative risk factors. The other approach consists of the standard strategy, in which a general protocol is administered and titration is performed according to the toxicity and efficacy [14]. When formulating an immune suppression protocol, clinicians should elaborate on the presence of comorbidities, drug toxicities, long-term exposure, and the potential recurrence of the original disease or malignancy. Newer protocols propose combinations of drugs with different mechanisms of action and toxicity profiles, thus targeting different pathways in the immune system to allow for dose minimization [15].

\section{Effects of Immune-Suppressive Agents on Recipients' Health}

Immunosuppression-related metabolic derangements (obesity, diabetes mellitus, dyslipidemia, and hypertension) affect clinical decisions about the choice of immunosuppressive agent. Moreover, these derangements have accelerated occurrence and have ominous outcomes that endanger grafts' durability and patients' survival [16-18]. Earlier reports claimed that the prevalence of post-liver-transplant metabolic syndrome ranges from 43 to $59 \%$ for transplants of any etiology and up to $90 \%$ in patients who received transplants for non-alcoholic fatty liver disease (NASH). Additionally, after a follow-up of 5 years, one-third of the recipients who developed metabolic derangements experienced one or more vascular accidents (CVD or stroke) [19,20]. Genetically predisposed recipients are at increased risk of developing metabolic side effects. Single-nucleotide polymorphisms (SNPs) in insulin receptor substrate (IRS-1) and hepatocyte nuclear factor-4 were associated with diabetes after kidney transplants. Recipients carrying multiple SNPs in other genes, including TCF7L2, KCNJ11-Kir6.2, and some variants of KCNQ1, as well as in diabetic genes, are at increased risk of post-transplant diabetes [21,22].

\subsection{Mechanisms of Metabolic Derangements Induced by Commonly Used Immunosuppressive Agents}

\subsubsection{Calcineurin Inhibitors}

Both tacrolimus (TAC) and cyclosporine A (CsA) decrease insulin secretion by inhibiting transcription factors for beta-cell growth and increased insulin resistance. CNI-induced diabetes is caused by the downregulation of adiponectin transcription and the induction of hypomagnesemia, which leads to impairment of insulin signaling [23]. Animal studies showed that tacrolimus is more diabetogenic both in vivo and in vitro. Calcineurin inhibitors induce hypertension by inducing systemic and renal vasoconstriction. Cyclosporin$\mathrm{A}$ is a lipogenic drug; it inhibits hepatic hydroxylase and decreases cholesterol degradation and bile acid synthesis [24-26].

\subsubsection{Mammalian Target of Rapamycin Inhibitors}

MTORis are known to induce hyperlipidemia through several mechanisms. They lead to an increase in free fatty acids, which leads to increased hepatic synthesis of triglycerides [27]. Sirolimus leads to alteration of insulin signaling pathways through the induction of protein-kinase-dependent phosphorylation for insulin receptor substrate 1 (IRS-1), resulting in suppression of the phosphatidylinositol pathway, which leads to decreased insulin receptor activation [28].

\subsubsection{Steroids}

Steroids are known to induce diabetes mellitus, hypertension, and hyperlipidemia. Most of the currently used immunosuppression protocols limit the use of steroids to the induction phase and/or acute/chronic rejection. However, a randomized trial for kidney transplant recipients concluded that steroid withdrawal did not decrease the incidence of post-transplant diabetes (PTDM) when compared to maintaining a low dose of steroids ( $<5 \mathrm{mg}$ /day). The role of steroids in PTDM is complementary to that of other immunosuppressive medications [28]. 


\subsection{Approach to the Management of Common Post-Transplant Metabolic Derangements}

Multiple risk factors have been identified for new onsets of metabolic derangements after a transplant; the use of CNIs is the most influential factor. Additionally, renal impairment is an exceptionally important clinical obstacle that clinicians face when dealing with transplant recipients. It is one of the leading causes of morbidity, including hospital admission post-LT, especially in the first year post-LT. Due to their potency as immunosuppressive agents, the primary step for management is a minimization of the doses of CNIs [29].

(i) Post-transplant hypertension is the most commonly reported metabolic derangement; it is estimated that $\sim 66 \%$ of liver transplant recipients develop hypertension shortly after transplantation [30]. Calcium channel blockers (CCBs), due to their vasodilator properties, are an effective treatment, especially in CNI-induced hypertension. Some calcium channel blockers, such as Nifedipine, inhibit intestinal cytochrome P450, thus increasing the level of CNIs. Angiotensin-converting enzyme (ACE) inhibitors and angiotensin receptor blockers (ARBs) are effective and potent treatments, but they require close monitoring, as they can induce hyperkalemia. Non-selective betablockers are also effective, but are not as potent as CCBs and ACE inhibitors [31].

(ii) For the management of PTDM, insulin therapy, especially early after an operation, represents the cornerstone. Metformin showed potential in animal studies; however, it cannot be used in patients with renal impairments. Other antidiabetic agents, such as incretins, insulin sensitizers, and insulin secretagogues, are safe in LT recipients who have stable cardiac, renal, and hepatic functions [32].

(iii) Dyslipidemia management should be primarily through weight reduction. However, hyperlipidemia with MTORis may necessitate termination of its use. The true clinical dilemma in using hypolipidemic drugs, especially statins, is their interaction with cytochrome P450, which metabolizes CNIs. The use of statins that do not interfere with cytochrome P450 (e.g., pravastatin and rosuvastatin) or the use of fish oil and fibrates can be an alternative. Fibrates can be nephrotoxic and they may lower the level of CsA, but they are used as first-line agents in MTORi-induced hypertriglyceridemia. Ezetimibe can be used as a monotherapy to decrease LDL levels without affecting immunosuppression levels [33].

(iv) Post-LT obesity leads to accelerated graft steatosis, exacerbation of hypertension, and deterioration of renal function, especially in patients who received transplants due to NASH [34]. Dietary interventions, pharmacologic treatment, and post-transplant bariatric surgery are the available treatment options. For the medical treatment of obesity, lorcaserin, naltrexone, and bupropion have important drug-drug interactions with CNIs. For bariatric surgery, its impact is variable between individuals, as the absorption of immunosuppressive drugs is highly affected by the type of bariatric surgery. For example, sleeve gastrectomy leads to a 40\% decrease in MMF absorption because it is absorbed in the stomach. On the other hand, the absorption of TAC and MTORi decreases by $50 \%$ in patients who undergo gastric bypass operations, as their absorption is affected by intestinal cytochrome P450 [35].

\subsection{Approach to the Management of Common Non-Metabolic Adverse Effects}

For the non-metabolic side of adverse effects, post-LT recurrence of hepatitis $C$ virus and hepatitis $B$ virus is a major cause of graft loss. HCV recurrence leads to progressive hepatic fibrosis. It is believed that HCV recurrence leads to accelerated cirrhosis within 9 years post-LT [36]. Minimization of the dose of immunosuppression has been correlated with better post-LT outcomes in patients with recurrent viral hepatitis [37]. An earlier report described that HCV-positive transplant recipients who were treated with everolimus and were exposed to lower doses of tacrolimus had a reduction in liver fibrosis progression [38]. HBV infection was considered a relative contraindication to LT because immunosuppression leads to uncontrolled viral replication, leading to progressive hepatic injury even after 
immunosuppressive agents are reduced. The use of hepatitis B immunoglobulin HBIg and antivirals for HBV reduces recurrence and prevents recurrence-related liver injury [39,40].

For HCC patients, post-LT recurrence is correlated with trough levels of immunosuppressive agents. A report described three-fold increase in HCC recurrence in recipients who were maintained on $>10 \mathrm{ng} / \mathrm{mL}$ TAC or $>300 \mathrm{ng} / \mathrm{mL}$ CsA [41]. MTOR inhibitors have anti-proliferative properties. They help in the prevention of HCC recurrence and/or the stabilization of progression in recurrent HCC after LT, especially if combined with Sorafenib [42-44]. In a systematic review, the use of MTORi was associated with lower recurrence than with CNI monotherapy; $8 \%$ of patients who received MTORi experienced recurrence vs. $13.8 \%$ in the patients who received CNIs, with a median follow-up of 36 (range: 11-97) months $(p<0.001)$ [45].

\section{Effect of Immunosuppression on Health-Related Quality of Life}

Immunosuppressive agents possess a huge impact on health-related quality of life (HRQoL). The HRQoL for transplanted patients includes mental, social, and physical health [20]. Financial support and employability post-LT are top priorities for recipients and their caregivers, especially with the high cost of immunosuppressive medications. It is estimated that $20 \%$ of the unemployed LT recipients in the USA prefer unemployment in post-transplant life for fear of losing their insurance coverage [46]. According to an analysis of OPTN/UNOS data on insurance coverage for liver transplant recipients, Medicare contributes to $\sim 85 \%$ of the insurance coverage, especially with increasing age [47].

\section{Pregnancy and Lactation in Immunosuppressed Patients}

Regaining fertility after transplantation is one indicator of regaining full functional capacity. Immunosuppressive medications, except for MMF, have high safety profiles for pregnancy and lactation [48]. Pregnancy is considered as a state of immune suppression, with the uterus being a more immune-privileged organ. The impact of this finding on the tolerance/rejection of transplanted organs has not been explored [49]. Complications related to immunosuppressive drugs include those of fetal health, maternal health, and graft health. Intrauterine growth retardation, fetal death, and perinatal asphyxia have a two- to three-fold increase in transplant recipients. A wide spectrum of fetal malformations with the use of MMF have been described [50] (Figure 1). A systematic review of pregnancy outcomes after LT, which included thirty-eight studies with $~ 850$ transplant recipients, emphasized that fetal complications were higher than in the general population. For maternal complications, pre-eclampsia and pregnancy-induced hypertension were the most commonly reported complications [51].

Precautions for pregnant transplant recipients include the close monitoring of creatinine for any subtle rises, as these may indicate the deterioration of kidney function, thus necessitating the modification of the immunosuppressive drug doses. Regular blood count checks are also suggested, as the physiologic anemia associated with pregnancy is exacerbated by immunosuppressive medications. Additionally, the increased plasma volume with pregnancy leads to the dilution of drugs. However, dose escalation should be avoided in order to prevent toxicity. Despite being multifactorial, for gestational diabetes and pregnancy-induced hypertension, including pre-eclampsia, there is a higher incidence with the use of immunosuppressive medications. The minimization of immunosuppression during pregnancy may be a clinical necessity; however, the target trough levels are individualized for each patient [52,53] (Table 2). 


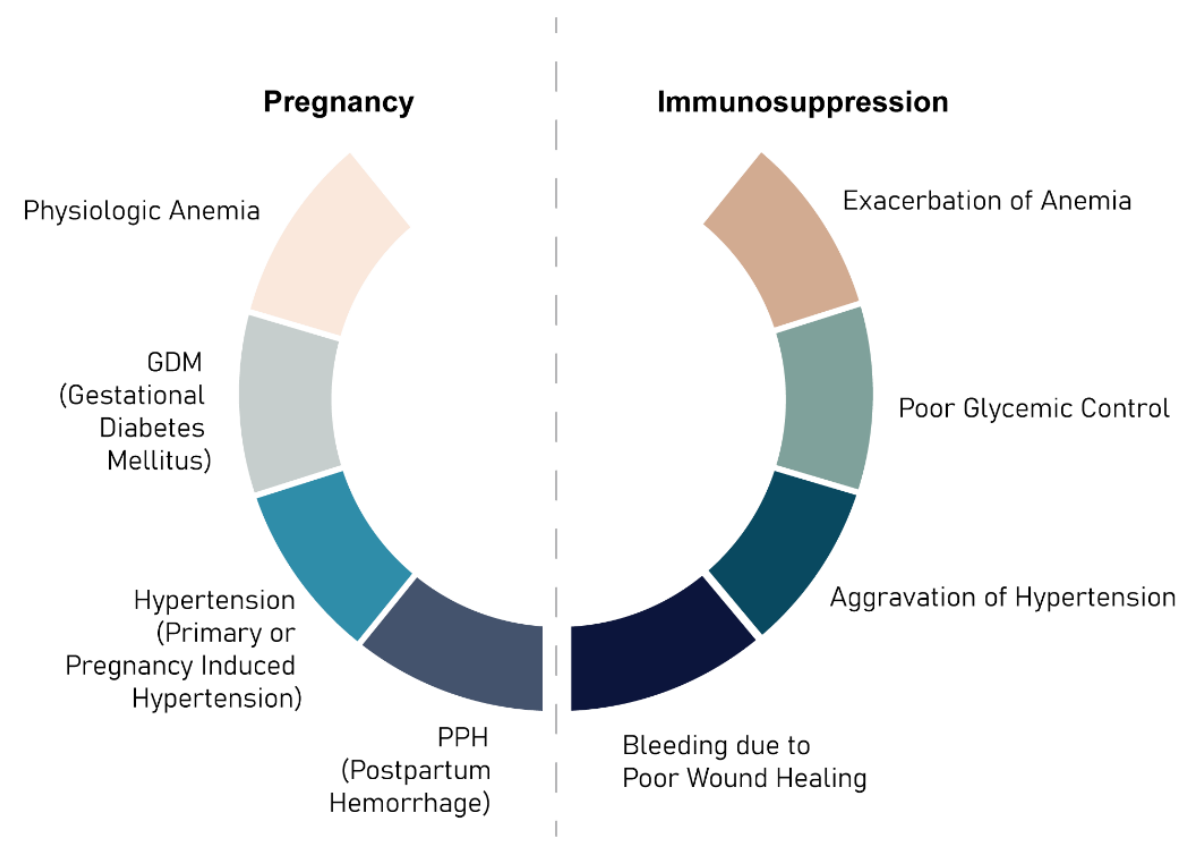

Figure 1. Interplay between pregnancy and immunosuppressive medications.

Table 2. Common side effects of immunosuppressive drugs on maternal health.

\begin{tabular}{cc}
\hline Drug Class & Effect of Maternal Health \\
\hline Corticosteroids & Hypertension, diabetes mellitus, weight gain, delayed wound healing \\
\hline Calcineurin inhibitors & $\begin{array}{c}\text { Hypertension, diabetes mellitus, renal impairment, } \\
\text { pregnancy-induced hypertension }\end{array}$ \\
\hline MMF & $\begin{array}{c}\text { Increased infection, not recommended during pregnancy } \\
\text { due to teratogenicity }\end{array}$ \\
\hline MTORi & Increased infection, GI side effects \\
\hline
\end{tabular}

For lactation, the decision should be weighed according to the benefits and risks to the child's and mother's health. The fraction of the drug excreted in breast milk should be evaluated in correlation with the dose on the basis of measuring the neonatal immunosuppressant blood level. Because nearly half of the neonates of transplant recipients have a low birth weight or IUGR, the importance of breastfeeding in this context has been well documented. On the other hand, stable graft function is a limiting factor for the decision of immunosuppressive drug dosing. Generally, steroids and Tacrolimus are considered safe in lactating females [54].

\section{Strategies for Immune Suppression Withdrawal/Minimization}

Post-transplant survival requires comprehensive care. Routine medical care postLT should include the early detection of possible adverse events of immunosuppressive drugs. Patients should be monitored for the development of cardiovascular diseases, renal impairments, diabetes mellitus, malignancies, and osteoporosis for the best outcomes. Monitoring of dental health, mental health, sexual function, and immunization should also be provided [55].

Dose minimization/withdrawal of immunosuppression is associated with better outcomes in terms of decreased morbidity and mortality. A study of 275 liver transplant recipients with $\mathrm{HCV}$ or nonimmune and non-viral liver disease was conducted to test the effects of early immunosuppression withdrawal on liver transplant recipients. The study concluded that the complete withdrawal of immunosuppressive drugs was successful only in a few patients. The result of this trial highlighted the importance of the presence 
of specific criteria for recipients who can benefit from immunosuppression withdrawal. In this study, graft health was monitored by using a liver biopsy, which is invasive and requires trained physicians. The lack of specific predictors for possible rejections represents an enigma, as the elimination and modification of doses would be matters of trial and error [56].

Multiple studies tested the safety of immunosuppression withdrawal with respect to long-term graft survival. However, the ability to reverse graft injury after withdrawal is still debatable. This is why most studies tested gradual withdrawal in patients with stable graft function in order to avoid unpredicted rejection episodes $[57,58]$ Table 3.

Table 3. Trials for immunosuppression withdrawal.

\begin{tabular}{|c|c|c|c|c|c|c|}
\hline Study & Population & Type & Duration of Withdrawal & $\begin{array}{c}\text { Total } \\
\text { Subjects }\end{array}$ & $\begin{array}{c}\text { Successful } \\
\text { Withdrawal Arm }\end{array}$ & Follow Up \\
\hline $\begin{array}{c}\text { Feng/iWITH } \\
\text { Study [59] }\end{array}$ & Pediatrics & Multicenter & $36-48$ weeks & 2909 & $\begin{array}{c}37.5 \% \% \text { of } 88 \\
\text { subjects }\end{array}$ & $1,2,3,4$ years \\
\hline Levitsky [60] & Adults & $\begin{array}{l}\text { Single } \\
\text { center }\end{array}$ & $\begin{array}{l}>3 \text { years post-LTWithdrawal } \\
\text { over } 6 \text { months }\end{array}$ & 1255 & $\begin{array}{l}>50 \% \text { of } 15 \\
\text { subjects }\end{array}$ & 1 year \\
\hline Benitez [61] & Adults & Multicenter & $\begin{array}{l}>3 \text { years post-LTWithdrawal } \\
\text { over } 6-9 \text { months }\end{array}$ & 500 & $40 \%$ of 98 subjects & Up to 3 years \\
\hline Pons [62] & Adults & $\begin{array}{l}\text { Single } \\
\text { center }\end{array}$ & $>2$ years post-LT & 490 & $42 \%$ of 12 subjects & 2 years \\
\hline
\end{tabular}

In efforts to eliminate CNIs, MTOR inhibitors were tested-as a monotherapy or in combination with a reduced dose of CNIs-for their ability to maintain graft function and prevent graft loss. A consensus for when to start MTORis has still not been reached, as early introduction within one month post-LT is associated with hepatic artery (HA) thrombosis. Starting MTORis within one month post-LT was shown to result in the fewest incidences of HA thrombosis. Another clinical dilemma is that of target trough levels. In the H2304 study, everolimus (MTORi) was initiated at 1 month after transplantation. The target trough level was 3-8 ng/mL, which resulted in fewer adverse events as compared to the results of other studies that used higher levels of everolimus [61-64]. Minimization of the dose of CNIs improved renal function, decreased post-transplant diabetes, and reduced viral hepatitis and HCC recurrence. However, everolimus has considerable side effects, and the reno-protective effect of everolimus was more prominent in candidates with GFR $70>55 \mathrm{~mL} / \mathrm{min}$ [65].

A recent consensus by an Italian working group using the Delphi methodology tested the use of everolimus in LT. Everolimus facilitated a reduction in CNI doses as early as 10 days post-transplant, and conversion to CNI-free protocols could be achieved by 12 months post-LT [66]. On the other hand, the results of a recently published Cochrane meta-analysis of 26 trials for the maintenance of immunosuppression in adults after liver transplantation were discouraging. The authors concluded that, at a maximal follow-up horizon, the combination of CNIs and MTORis was associated with increased mortality and graft loss. They attributed the result to the low quality of evidence in the published data and selection bias. The follow-ups ranged from 3 to 144 months post-transplant. However, in attempts to prevent graft loss, most of the available trials have had high rates of patient dropout and/or cross-over [67].

\section{Immune Tolerance and Its Application in the Liver Transplant Setting: From Bench to Bedside}

Medawar et al. first described the induction of immune tolerance more than 60 years ago. Immune tolerance is defined as immune unresponsiveness to foreign allografts. Achieving immune tolerance is the ultimate goal in order to overcome the need to use long-term immunosuppressive drugs and minimize the subsequent deleterious health effects. Liver grafts show a large degree of immune tolerance, and experimental trials on 
the withdrawal immunosuppression have been promising, but evidence for use in clinical settings is lacking [68].

$\mathrm{T}$ lymphocytes play an important role in graft immune response for either tolerance or rejection. The balance between cytotoxic T cells and CD4+CD25+FOXP3+ regulatory $\mathrm{T}$ cells (Tregs) is the basis of most tolerance protocols. Recipients' $\mathrm{T}$ cells can recognize the donor antigens through both the self and donor antigen-presenting cells (APCs), then undergo expansion and increase the activation of host and donor cells to attack the foreign antigens. Tregs can halt this immune response and induce donor antigen immune tolerance through the inhibition of cytotoxic cell proliferation, stopping of cytokine production, and prevention of antibody production [69]. The liver has a variety of immune cells, such as dendritic cells, Kupffer cells, hepatic stellate cells, and liver sinusoid endothelial cells. These cells are capable of modifying the immune response and inducing proliferation in order to tolerate Tregs. However, this immune response is unpredictable, and its sustainability in the absence of immunosuppressive medications is questionable [13].

Regulatory cells in the response of immune tolerance can be modulated with donormodified cell therapy. This has been demonstrated in animal models by the ability of donor-treated dendritic cells (DCs) to induce production of granulocyte-macrophage colony-stimulating factors (GM_CSFs) for the proliferation of tolerating cells. A study demonstrated the rejection of liver grafts in transgenic animal models that were DC depleted. Another report concluded that Tregs can interact with DCs, and the interaction resulted in the removal of foreign antigens and MHC class II from their surface, leading to a reduction of their ability of to present foreign alloantigen to alloreactive $\mathrm{T}$ cells [70,71]. Another APC is the liver sinusoid endothelial cell (LSEC), which can induce antigen presentation and programmed cell death (PD) as well. The PD ligand is capable of inducing apoptosis in alloreactive $\mathrm{T}$ cells and antigen-specific $\mathrm{T}$ cells; this was demonstrated in animal models. Moreover, they can induce tolerance of reactive B cells, allowing for tolerance of ABO-incompatible grafts. Hepatic stellate cells (HSCs) were suggested to induce a similar effect in LESCs in animal models that led to immune tolerance for transplanted grafts. Other animal studies of cellular immune-tolerance-inducing therapy showed the importance of liver immune cells in modulating the host's immune response to the transplanted graft [72,73] (Figure 2).

To date, multiple clinical trials have shown promising results when using Tregs in transplantation with the subsequent elimination of immune suppression and induction of immune tolerance. A UCSF group (trial \#NCT02474199), Kings College group (trial \#NCT02166177), and Massachusetts general hospital group (trial \#NCT03577431) introduces the use of regulatory $\mathrm{T}$ cells (Tregs) for liver transplantation in a clinical setting [13] (Table 4).

The interplay between graft immune cells and host cells is the cornerstone for this immune tolerance effect. APCs from the graft activate Tregs, which secrete, e.g., IL 10, TGF-B, and INF gamma. This leads to the suppression of DCs and effector cells, leading to immune tolerance. It is suggested that this immune response is short-lived, as levels of Tregs drop within 2 weeks. A report suggested infusion of IL2, which maintained the population of Tregs to increase the duration of the tolerating response. IL2 infusion was deemed safe; however, it did not lead to a maintained long-lived response. The tolerating Treg populations were observed to be higher in patients receiving MTORi immune suppression in one study $[74,75]$. The use of Treg therapy in LT was demonstrated in some living-donor transplant (LDLT) trials; the enrolled patients had to start the induction of immunosuppressive therapy, and the timing of withdrawal of the immunosuppressive drugs was variable. However, some candidates were only recruited if the graft function was stable for up to 6 years post-transplant [76]. A pilot study for operational tolerance with regulatory Tregs in LDLT was terminated due to the development of acute rejection in the intervention group. However, the rejection occurred in patients who received transplants due to autoimmune hepatitis. The patients who received transplants due to non-immune liver diseases showed the best results in terms of successful withdrawal of 
immunosuppression and induction of tolerance. This result highlights that the molecular and genetic characteristics of patients are a driving force of immune tolerance [77].

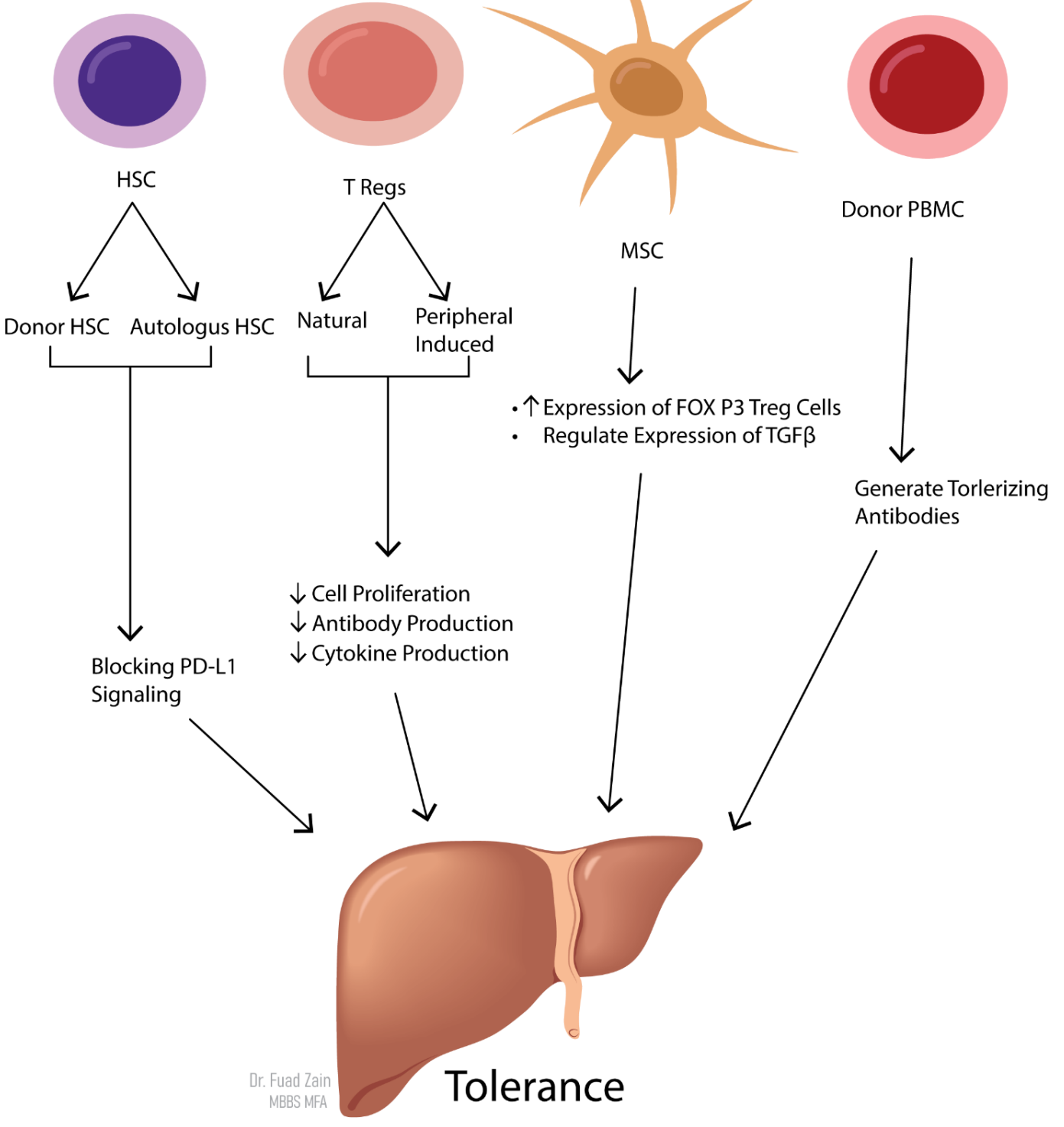

Figure 2. Cellular immune suppression.

Table 4. Summary of trials in studies of Tregs in liver transplantation.

\begin{tabular}{|c|c|c|c|c|}
\hline Trial Name & Induction Therapy & $\begin{array}{c}\text { Immunosuppressive } \\
\text { Regimen }\end{array}$ & Timing of Start of Tregs & Status \\
\hline $\begin{array}{c}\text { ARTEMIS } \\
\text { NCT02474199 }\end{array}$ & Yes (ATG) & CNI based & $2-6$ years post-transplant & Completed \\
\hline $\begin{array}{c}\text { ThRIL } \\
\text { NCT02166177 }\end{array}$ & Yes (ATG) & CNI and MTORi & 2 months & Completed \\
\hline $\begin{array}{c}\text { ITN073ST } \\
\text { NCT03577431 }\end{array}$ & $\begin{array}{c}\text { Yes } \\
\text { (cyclocphosphamide) }\end{array}$ & EVR and TAC & 2-6 months & Recruiting \\
\hline $\begin{array}{l}\text { DAIT RTB-002 } \\
\text { NCT02188719 }\end{array}$ & Yes (ATG) & $\begin{array}{l}\text { TAC+ MMF } \\
\text { EVR+ rTAC }\end{array}$ & Early post-LT & Terminated \\
\hline
\end{tabular}




\section{Deliberation on Strategies to Improve Immune Suppression Practice}

There are multiple potential aspects in assessing the efficacy of cellular immune suppression for the induction of immune tolerance. The prediction of the sustainability of the response is the next challenge in achieving a consensus and improving patient selection criteria. Another challenge is the development of surrogates for liver biopsies for monitoring, as the role of the protocol biopsy is declining in liver transplantation in order to improve patients' adherence to surveillance protocols. The third challenge is the optimal timing for immunosuppression withdrawal and how early it can be achieved [78] (Figure 3).

\section{Immunosupression Protocol}

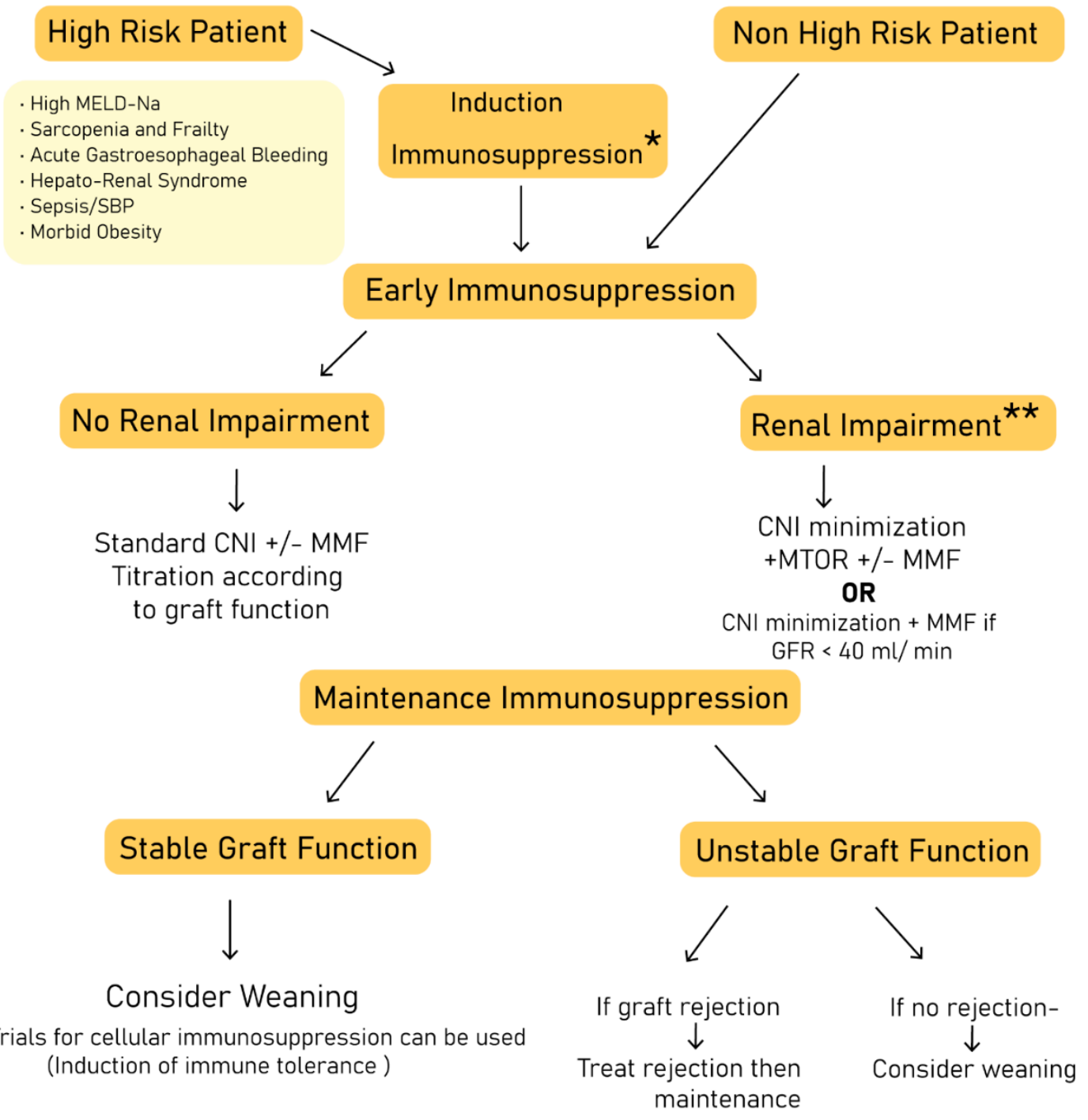

Non high risk patients if Intraoperative bleeding, shock and other major complications

$\star \star$ Sustained Increase in Creatinine and decrease in GFR

Figure 3. Formulation of an immune suppression protocol for liver transplant recipients. 


\section{Conclusions}

Extending the scope of immune suppression to immune tolerance is a promising strategy for overcoming the deleterious effects of immunosuppressive medications. Challenges to the abilities of cellular therapy in a clinical setting are efficacy, sustainability, and cost effectiveness, which should be the focus of clinical trials of the induction of immune tolerance. Today, the minimization of exposure to CNIs and the growing clinical interest in shifting to everolimus-based therapy represent the current hope of overcoming the deleterious health effects of CNIs. With the increasing survival of liver transplant recipients, guidance for optimal immune modulation through either suppression of immunity or induction of tolerance should focus on the prediction of the long-term outcomes of the patient and the overall health of the graft.

Author Contributions: All authors approved the final version of the manuscript. I.B.M.: Study concept, design, literature review, and drafting of the manuscript. F.Z.A.: drafting of the manuscript and creation of the illustrations. P.K.J.: Study concept, design, literature review, and drafting of the manuscript. All authors: Critical revision of the manuscript. All authors have read and agreed to the published version of the manuscript.

Funding: This research received no external funding.

Conflicts of Interest: There are none to declare for any of the authors related to the current study.

$\begin{array}{ll}\text { Abbreviations } \\ \text { LT } & \text { Liver transplantation } \\ \text { CNIs } & \text { Calcineurin inhibitors } \\ \text { CsA } & \text { Cyclosporine A } \\ \text { TAC } & \text { Tacrolimus } \\ \text { rTAC } & \text { Reduced Tacrolimus } \\ \text { MTORi } & \text { Mammalian target of Rapamycin inhibitors } \\ \text { MMF } & \text { Mycophenolic acid } \\ \text { ATG } & \text { Antithymocyte globulin } \\ \text { IS } & \text { Immunosuppressive } \\ \text { Tregs } & \text { Regulatory T cells } \\ \text { CVD } & \text { Cardiovascular diseases; } \\ \text { PTDM } & \text { Post-transplant diabetes mellitus } \\ \text { NASH } & \text { Non-alcoholic fatty liver disease } \\ \text { HCC } & \text { Hepatocellular carcinoma } \\ \text { HRQL } & \text { Health-related quality of life } \\ \text { AMR } & \text { Antibody-mediated rejection } \\ \text { HCV } & \text { Hepatitis C virus } \\ \text { HBV } & \text { Hepatitis B virus }\end{array}$

\section{References}

1. Neuberger, J. Follow-up of liver transplant recipients. Best Pract. Res. Clin. Gastroenterol. 2020, 46-47, 101682. [CrossRef]

2. Scientific Registry of Transplant Recipients. Available online: https://srtr.transplant.hrsa.gov/annual_reports/2016/Economics. aspx\#Econ_3_LI_tx_medicare_cov_1_b64 (accessed on 20 August 2021).

3. Serper, M.; Reese, P.P.; Patzer, R.R.; Levitsky, J.; Wolf, M.S. The prevalence, risk factors, and outcomes of medication trade-offs in kidney and liver transplant recipients: A pilot study. Transpl. Int. 2018, 31, 870-879. [CrossRef]

4. $\quad$ Leighton, J.; Wilson, C. Modern immunosuppression. Surgery 2020, 38, 368-374. [CrossRef]

5. Tasdogan, B.E.; Ma, M.; Simsek, C.; Saberi, B.; Gurakar, A. Update on immunosuppression in liver transplantation. Euroasian J. Hepato Gastroenterol. 2019, 9, 96-101. [CrossRef]

6. Zarrinpar, A.; Busuttil, R.W. Liver transplantation: Past, present and future. Nat. Rev. Gastroenterol. Hepatol. 2013, 10, 434-440. [CrossRef]

7. Geissler, E.K.; Schlitt, H.J. Immunosuppression for liver transplantation. Gut 2009, 58, 452-463. [CrossRef] [PubMed]

8. Ojo, A.O.; Held, P.J.; Port, F.K.; Wolfe, R.A.; Leichtman, A.B.; Young, E.W.; Arndorfer, J.; Christensen, L.; Merion, R.M. Chronic renal failure after transplantation of a nonrenal organ. N. Engl. J. Med. 2003, 349, 931-940. [CrossRef] 
9. Liu, C.L.; Fan, S.T.; Lo, C.M.; Chan, S.C.; Ng, I.O.; Lai, C.L.; Wong, J. Interleukin-2 receptor antibody (basiliximab) for immunosuppressive induction therapy after liver transplantation: A protocol with early elimination of steroids and reduction of tacrolimus dosage. Liver Transplant. 2004, 10, 728-733. [CrossRef]

10. Magliocca, J.F.; Knechtle, S.J. The evolving role of alemtuzumab (Campath-1H) for immunosuppressive therapy in organ transplantation. Transpl. Int. 2006, 19, 705-714. [CrossRef] [PubMed]

11. Vincenti, F.; Mendez, R.; Pescovitz, M.; Rajagopalan, P.R.; Wilkinson, A.H.; Butt, K.; Laskow, D.; Slakey, D.P.; Lorber, M.I.; Garg, J.P.; et al. A phase I/II randomized open-label multicenter trial of efalizumab, a humanized anti-CD11a, anti-LFA-1 in renal transplantation. Am. J. Transplant. 2007, 7, 1770-1777. [CrossRef]

12. Hutchinson, J.A.; Brem-Exner, B.G.; Riquelme, P.; Roelen, D.; Schulze, M.; Ivens, K.; Grabensee, B.; Witzke, O.; Philipp, T.; Renders, L.; et al. A cell-based approach to the minimization of immunosuppression in renal transplantation. Transpl. Int. 2008, 21, 742-754. [CrossRef]

13. Tanimine, N.; Ohira, M.; Tahara, H.; Ide, K.; Tanaka, Y.; Onoe, T.; Ohdan, H. Strategies for deliberate induction of immune tolerance in liver transplantation: From preclinical models to clinical application. Front. Immunol. 2020, 11, 1615. [CrossRef] [PubMed]

14. De Simone, P.; Carrai, P.; Coletti, L.; Ghinolfi, D.; Petruccelli, S.; Filipponi, F. Modification of immunosuppressive therapy as risk factor for complications after liver transplantation. Best Pract. Res. Clin. Gastroenterol. 2017, 31, 199-209. [CrossRef]

15. Cillo, U.; De Carlis, L.; Del Gaudio, M.; De Simone, P.; Fagiuoli, S.; Lupo, F.; Tisone, G.; Volpes, R.; Avolio, A.; Bitetto, D.; et al. Correction to: Immunosuppressive regimens for adult liver transplant recipients in real-life practice: Consensus recommendations from an Italian Working Group. Hepatol. Int. 2021, 14, 930-943. [CrossRef]

16. Berglund, D.; Bengtsson, M.; Biglarnia, A.; Berglund, E.; Yamamoto, S.; Von Zur-Mühlen, B.; Lorant, T.; Tufveson, G. Screening of mortality in transplant patients using an assay for immune function. Transpl. Immunol. 2011, 24, 246-250. [CrossRef] [PubMed]

17. Spiritos, Z.; Abdelmalek, M.F. Metabolic syndrome following liver transplantation in nonalcoholic steatohepatitis. Transl. Gastroenterol. Hepatol. 2021, 6, 13. [CrossRef]

18. Cotter, T.G.; Charlton, M. Nonalcoholic Steatohepatitis after Liver Transplantation. Liver Transplant. 2020, 26, 141-159. [CrossRef]

19. Anastácio, L.R.; Lima, A.S.; Correia, M.I.T.D. Metabolic syndrome and its components after liver transplantation: Incidence, prevalence, risk factors, and implications. Clin. Nutr. 2010, 29, 175-179. [CrossRef]

20. Pagadala, M.; Dasarathy, S.; Eghtesad, B.; McCullough, A.J. Posttransplant metabolic syndrome: An epidemic waiting to happen. Liver Transplant. 2009, 15, 1662-1670. [CrossRef] [PubMed]

21. Sharif, A.; Hecking, M.; de Vries, A.P.J.; Porrini, E.; Hornum, M.; Rasoul-Rockenschaub, S.; Berlakovich, G.; Krebs, M.; KautzkyWiller, A.; Schernthaner, G.; et al. Proceedings from an international consensus meeting on posttransplantation diabetes mellitus: Recommendations and future directions. Am. J. Transplant. 2014, 14, 1992-2000. [CrossRef]

22. Yang, J.; Hutchinson, I.I.; Shah, T.; Min, D.I. Genetic and clinical risk factors of new-onset diabetes after transplantation in hispanic kidney transplant recipients. Transplantation 2011, 91, 1114-1119. [CrossRef] [PubMed]

23. Van Laecke, S.; Desideri, F.; Geerts, A.; Van Vlierberghe, H.; Berrevoet, F.; Rogiers, X.; Troisi, R.; De Hemptinne, B.; Vanholder, R.; Colle, I. Hypomagnesemia and the risk of new-onset diabetes after liver transplantation. Liver Transplant. 2010, 16, $1278-1287$. [CrossRef]

24. Lane, J.T.; Dagogo-Jack, S. Approach to the patient with new-onset diabetes after transplant (NODAT). J. Clin. Endocrinol. Metab. 2011, 96, 3289-3297. [CrossRef] [PubMed]

25. Hryniewiecka, E.; Żegarska, J.; Pa $<$ monospace $></$ monospace $>$ czek, L. Arterial hypertension in liver transplant recipients. Transplant. Proc. 2011, 43, 3029-3034. [CrossRef]

26. Shivaswamy, V.; Boerner, B.; Larsen, J. Post-transplant diabetes mellitus: Causes, treatment, and impact on outcomes. Endocr. Rev. 2016, 37, 37-61. [CrossRef]

27. Hakeam, H.A.; Al-Jedai, A.H.; Raza, S.M.; Hamawi, K. Sirolimus induced dyslipidemia in tacrolimus based vs. tacrolimus free immunosuppressive regimens in renal transplant recipients. Ann. Transplant. 2008, 13, 46-53. [PubMed]

28. Khullar, V.; Dolganiuc, A.; Firpi, R.J. Pre-and-post transplant considerations in patients with nonalcoholic fatty liver disease. World J. Transplant. 2014, 4, 81-92. [CrossRef]

29. Stone, N.; Robinson, J.G.; Lichtenstein, A.H.; Merz, C.N.B.; Blum, C.B.; Eckel, R.H.; Goldberg, A.C.; Gordon, D.; Levy, D.; Lloyd-Jones, D.; et al. 2013 ACC/AHA guideline on the treatment of blood cholesterol to reduce atherosclerotic cardiovascular risk in adults. Circulation 2014, 129, S1-S45. [CrossRef] [PubMed]

30. Neal, D.A.J.; Brown, M.J.; Wilkinson, I.B.; Alexander, G.J.M. Mechanisms of hypertension after liver transplantation. Transplantation 2005, 79, 935-940. [CrossRef]

31. Pirsch, J.D.; Henning, A.K.; First, M.R.; Fitzsimmons, W.; Gaber, A.O.; Reisfield, R.; Shihab, F.; Woodle, E.S. New-onset diabetes after transplantation: Results from a double-blind early corticosteroid withdrawal trial. Am. J. Transplant. 2015, 15, 1982-1990. [CrossRef]

32. Aroda, V.R.; Ratner, R. The safety and tolerability of GLP-1 receptor agonists in the treatment of type 2 diabetes: A review. Diabetes Metab. Res. Rev. 2011, 27, 528-542. [CrossRef]

33. Laryea, M.; Watt, K.D.; Molinari, M.; Walsh, M.J.; McAlister, V.C.; Marotta, P.J.; Nashan, B.; Peltekian, K.M. Metabolic syndrome in liver transplant recipients: Prevalence and association with major vascular events. Liver Transplant. 2007, 13, 1109-1114. [CrossRef] 
34. Houlihan, D.D.; Armstrong, M.J.; Davidov, Y.; Hodson, J.; Nightingale, P.; Rowe, I.A.; Paris, S.; Gunson, B.K.; Bramhall, S.B.; Mutimer, D.J.; et al. Renal function in patients undergoing transplantation for nonalcoholic steatohepatitis cirrhosis: Time to reconsider immunosuppression regimens? Liver Transplant. 2011, 17, 1292-1298. [CrossRef]

35. McGuire, B.M.; Rosenthal, P.; Brown, C.C.; Busch, A.M.H.; Calcatera, S.M.; Claria, R.S.; Hunt, N.K.; Korenblat, K.M.; Mazariegos, G.V.; Moonka, D.; et al. Long-term management of the liver transplant patient: Recommendations for the primary care doctor. Am. J. Transplant. 2009, 9, 1988-2003. [CrossRef]

36. Vinaixa, C.; Rubín, A.; Aguilera, V.; Berenguer, M. Recurrence of hepatitis C after liver transplantation. Ann. Gastroenterol. 2013, $26,304-313$.

37. Albekairy, A.M.; Abdel-Razaq, W.S.; Alkatheri, A.M.; Al Debasi, T.M.; Alotaibi, N.; Qandil, A.M. The impact of immunosuppressant therapy on the recurrence of hepatitis C post-liver transplantation. Int. J. Health Sci. 2008, 12, 78-87.

38. Saliba, F.; Nevens, F. Progression of liver fibrosis in HCV-positive liver transplant recipients randomized to everolimus with reduced calcineurin inhibitor (CNI) therapy or a standard CNI regimen. Transpl. Int. 2015, 28, 373-374. [CrossRef]

39. John, S.; Andersson, K.; Kotton, C.; Hertl, M.; Markmann, J.F.; Cosimi, A.B.; Chung, R.T. Prophylaxis of hepatitis B infection in solid organ transplant recipients. Ther. Adv. Gastroenterol. 2013, 6, 309-319. [CrossRef] [PubMed]

40. Nasir, M.; Wu, G.Y. Prevention of HBV recurrence after liver transplant: A review. J. Clin. Transl. Hepatol. 2020, 8, 150-160. [CrossRef] [PubMed]

41. Khorsandi, S.E.; Heaton, N. Optimization of immunosuppressive medication upon liver transplantation against HCC recurrence. Transl. Gastroenterol. Hepatol. 2016, 1, 25. [CrossRef]

42. Sposito, C.; Mariani, L.; Germini, A.; Reyes, M.F.; Bongini, M.; Grossi, G.; Bhoori, S.; Mazzaferro, V. Comparative efficacy of sorafenib versus best supportive care in recurrent hepatocellular carcinoma after liver transplantation: A case-control study. $J$. Hepatol. 2013, 59, 59-66. [CrossRef]

43. Finn, R.S.; Poon, R.T.; Yau, T.; Klümpen, H.-J.; Chen, L.-T.; Kang, Y.-K.; Kim, T.-Y.; Gomez-Martin, C.; Rodriguez-Lope, C.; Kunz, T.; et al. Phase I study investigating everolimus combined with sorafenib in patients with advanced hepatocellular carcinoma. J. Hepatol. 2013, 59, 1271-1277. [CrossRef]

44. Cholongitas, E.; Antoniadis, N.; Goulis, I.; Theocharidou, E.; Imvrios, G.; Giouleme, O.; Filis, D.; Mouloudi, E.; Akriviadis, E.; Fouzas, I. Trough levels of everolimus are associated with recurrence rates of hepatocellular carcinoma after liver transplantation. Transplant. Proc. 2019, 51, 450-453. [CrossRef]

45. Cholongitas, E.; Mamou, C.; Rodríguez-Castro, K.I.; Burra, P. Mammalian target of rapamycin inhibitors are associated with lower rates of hepatocellular carcinoma recurrence after liver transplantation: A systematic review. Transpl. Int. 2014, 27, 1039-1049. [CrossRef]

46. Åberg, F. From prolonging life to prolonging working life: Tackling unemployment among liver-transplant recipients. World J. Gastroenterol. 2016, 22, 3701-3711. [CrossRef] [PubMed]

47. Scientific Registry of Transplant Recipients. Available online: https://srtr.transplant.hrsa.gov/annual_reports/2019/Economics aspx\#ECON_tx_hosp_li_rec_oneyear_outcome_b64 (accessed on 20 August 2021).

48. Rahim, M.N.; Long, L.; Penna, L.; Williamson, C.; Kametas, N.A.; Nicolaides, K.H.; Heneghan, M.A. Pregnancy in liver transplantation. Liver Transplant. 2020, 26, 564-581. [CrossRef] [PubMed]

49. Rouas-Freiss, N.; Naji, A.; Durrbach, A.; Carosella, E.D. Tolerogenic functions of human leukocyte antigen G: From pregnancy to organ and cell transplantation. Transplantation 2007, 84, S21-S25. [CrossRef]

50. Kim, M.; Rostas, S.; Gabardi, S. Mycophenolate fetal toxicity and risk evaluation and mitigation strategies. Am. J. Transplant. 2013, 13, 1383-1389. [CrossRef] [PubMed]

51. Valentin, N.; Guerrido, I.; Rozenshteyn, F.; Pinotti, R.; Wu, Y.C.; Collins, K.; Shah, M.; Hershman, M.; Weisberg, I. Pregnancy outcomes after liver transplantation: A systematic review and meta-analysis. Am. J. Gastroenterol. 2021, 116, 491-504. [CrossRef]

52. Ghazali, S.; Czuzoj-Shulman, N.; Spence, A.R.; Mishkin, D.S.; Abenhaim, H.A. Pregnancy outcomes in liver transplant patients, a population-based study. J. Matern. Fetal Neonatal Med. 2017, 30, 261-266. [CrossRef]

53. Lim, T.Y.; Gonsalkorala, E.; Cannon, M.D.; Gabeta, S.; Penna, L.; Heaton, N.D.; Heneghan, M.A. Successful pregnancy outcomes following liver transplantation is predicted by renal function. Liver Transplant. 2018, 24, 606-615. [CrossRef]

54. Thiagarajan, K.; Arakali, S.R.; Mealey, K.J.; Cardonick, E.; Gaughan, W.J.; Davison, J.M.; Moritz, M.J.; Armenti, V.T. Safety considerations: Breastfeeding after transplant. Prog. Transplant. 2013, 23, 137-146. [CrossRef]

55. Kwon, H.; Jeon, J.; Kim, D.; Jang, H.; Sung, H.; Han, D.; Park, J.; Lee, J.; Huh, W.; Kim, S.; et al. Clinical impact of a protocolized kidney donor follow-up system. Transplant. Proc. 2019, 51, 692-700. [CrossRef]

56. Shaked, A.; DesMarais, M.R.; Kopetskie, H.; Feng, S.; Punch, J.D.; Levitsky, J.; Reyes, J.; Klintmalm, G.B.; Demetris, A.J.; Burrell, B.E.; et al. Outcomes of immunosuppression minimization and withdrawal early after liver transplantation. Am. J. Transplant. 2019, 19, 1397-1409. [CrossRef] [PubMed]

57. Feng, S.; Bucuvalas, J.C.; Mazariegos, G.V.; Magee, J.C.; Sanchez-Fueyo, A.; Spain, K.M.; Lesniak, A.; Kanaparthi, S.; Perito, E.; Venkat, V.L.; et al. Efficacy and safety of immunosuppression withdrawal in pediatric liver transplant recipients: Moving toward personalized management. Hepatology 2021, 73, 1985-2004. [CrossRef]

58. Levitsky, J.; Burrell, B.E.; Kanaparthi, S.; Turka, L.A.; Kurian, S.; Sanchez-Fueyo, A.; Lozano, J.J.; Demetris, A.; Lesniak, A.; Kirk, A.D.; et al. Immunosuppression withdrawal in liver transplant recipients on sirolimus. Hepatology 2020, 72, 569-583. [CrossRef] [PubMed] 
59. Benítez, C.; Londoño, M.-C.; Miquel, R.; Manzia, T.M.; Gonzalez-Abraldes, J.; Lozano, J.J.; Martínez-Llordella, M.; López, M.; Angelico, R.; Bohne, F.; et al. Prospective multicenter clinical trial of immunosuppressive drug withdrawal in stable adult liver transplant recipients. Hepatology 2013, 58, 1824-1835. [CrossRef]

60. Pons, J.A.; Revilla-Nuin, B.; Baroja-Mazo, A.; Ramírez, P.; Martínez-Alarcón, L.; Sánchez-Bueno, F.; Robles, R.; Rios, A.; Aparicio, P.; Parrilla, P. FoxP3 in peripheral blood is associated with operational tolerance in liver transplant patients during immunosuppression withdrawal. Transplanation 2008, 86, 1370-1378. [CrossRef]

61. Neuberger, J.M.; Mamelok, R.D.; Neuhaus, P.; Pirenne, J.; Samuel, D.; Isoniemi, H.; Rostaing, L.; Rimola, A.; Marshall, S.; Mayer, A.D.; et al. delayed introduction of reduced-dose tacrolimus, and renal function in liver transplantation: The 'ReSpECT' study. Am. J. Transplant. 2009, 9, 327-336. [CrossRef]

62. De Simone, P.; Nevens, F.; De Carlis, L.; Metselaar, H.J.; Beckebaum, S.; Saliba, F.; Jonas, S.; Sudan, D.; Fung, J.; Fischer, L.; et al. Everolimus with reduced tacrolimus improves renal function in de novo liver transplant recipients: A randomized controlled trial. Am. J. Transplant. 2012, 12, 3008-3020. [CrossRef] [PubMed]

63. Saliba, F.; De Simone, P.; Nevens, F.; De Carlis, L.; Metselaar, H.J.; Beckebaum, S.; Jonas, S.; Sudan, D.; Fischer, L.; Duvoux, C.; et al. Renal function at two years in liver transplant patients receiving everolimus: Results of a randomized, multicenter study. Am. J. Transplant. 2013, 13, 1734-1745. [CrossRef]

64. Fischer, L.; Saliba, F.; Kaiser, G.M.; De Carlis, L.; Metselaar, H.J.; De Simone, P.; Duvoux, C.; Nevens, F.; Fung, J.J.; Dong, G.; et al. Three-year outcomes in de novo liver transplant patients receiving everolimus with reduced tacrolimus: Follow-up results from a randomized, multicenter study. Transplantation 2015, 99, 1455-1462. [CrossRef]

65. De Simone, P.; Saliba, F.; Dong, G.; Escrig, C.; Fischer, L. Do patient characteristics influence efficacy and renal outcomes in liver transplant patients receiving everolimus? Clin. Transplant. 2015, 30, 279-288. [CrossRef]

66. De Simone, P.; Fagiuoli, S.; Cescon, M.; De Carlis, L.; Tisone, G.; Volpes, R.; Cillo, U. Use of everolimus in liver transplantation. Transplantation 2017, 101, 239-251. [CrossRef]

67. Rodríguez-Perálvarez, M.; Guerrero-Misas, M.; Thorburn, U.; Davidson, B.R.; Tsochatzis, E.; Gurusamy, K.S. Maintenance immunosuppression for adults undergoing liver transplantation: A network meta-analysis. Cochrane Database Syst. Rev. 2017, 2017, 356. [CrossRef] [PubMed]

68. Sánchez-Fueyo, A.; Strom, T.B. Immunological tolerance and liver transplantation. J. Hepatol. 2004, 41, 698-705. [CrossRef]

69. Sykes, M. Mixed Chimerism and Transplant Tolerance. Immunity 2001, 14, 417-424. [CrossRef]

70. Lu, L.; A Rudert, W.; Qian, S.; McCaslin, D.; Fu, F.; Rao, A.S.; Trucco, M.; Fung, J.; E Starzl, T.; Thomson, A.W. Growth of donor-derived dendritic cells from the bone marrow of murine liver allograft recipients in response to granulocyte/macrophage colony-stimulating factor. J. Exp. Med. 1995, 182, 379-387. [CrossRef] [PubMed]

71. Yokota, S.; Yoshida, O.; Ono, Y.; Geller, D.A.; Thomson, A.W. Liver transplantation in the mouse: Insights into liver immunobiology, tissue injury, and allograft tolerance. Liver Transplant. 2015, 22, 536-546. [CrossRef]

72. Akkaya, B.; Oya, Y.; Akkaya, M.; Al Souz, J.; Holstein, A.H.; Kamenyeva, O.; Kabat, J.; Matsumura, R.; Dorward, D.W.; Glass, D.D.; et al. Regulatory T cells mediate specific suppression by depleting peptide-MHC class II from dendritic cells. Nat. Immunol. 2019, 20, 218-231. [CrossRef] [PubMed]

73. Igarashi, Y.; Onoe, T.; Ohdan, H. The role of liver sinusoidal endothelial cells in induction of carbohydrate reactive B cells tolerance through the programmed death 1/programmed death ligand 1 pathway. Transplantation 2015, 99, 2325-2336. [CrossRef] [PubMed]

74. Chen, C.-H.; Kuo, L.-M.; Chang, Y.; Wu, W.; Goldbach, C.; Ross, M.A.; Stolz, D.B.; Chen, L.; Fung, J.; Lu, L.; et al. In vivo immune modulatory activity of hepatic stellate cells in mice. Hepatology 2006, 44, 1171-1181. [CrossRef] [PubMed]

75. Gratz, I.K.; Truong, H.-A.; Yang, S.H.-Y.; Maurano, M.M.; Lee, K.; Abbas, A.K.; Rosenblum, M.D. Cutting edge: Memory regulatory T cells require IL-7 and not IL-2 for their maintenance in peripheral tissues. J. Immunol. 2013, 190, $4483-4487$. [CrossRef] [PubMed]

76. Yu, J.; Liu, Z.; Li, C.; Wei, Q.; Zheng, S.; Saeb-Parsy, K.; Xu, X. Regulatory T cell therapy following liver transplantation. Liver Transplant. 2021, 27, 264-280. [CrossRef]

77. Todo, S.; Yamashita, K.; Goto, R.; Zaitsu, M.; Nagatsu, A.; Oura, T.; Watanabe, M.; Aoyagi, T.; Suzuki, T.; Shimamura, T.; et al. A pilot study of operational tolerance with a regulatory T-cell-based cell therapy in living donor liver transplantation. Hepatology 2016, 64, 632-643. [CrossRef]

78. Tang, Q.; Vincenti, F. Transplant trials with tregs: Perils and promises. J. Clin. Investig. 2017, 127, 2505-2512. [CrossRef] 